Willy Tinner • Feng Sheng Hu • Ruth Beer •

Petra Kaltenrieder • Brigitte Scheurer ·

Urs Krähenbühl

\title{
Postglacial vegetational and fire history: pollen, plant macrofossil and charcoal records from two Alaskan lakes
}

Received: 28 July 2005 / Accepted: 23 December 2005 / Published online: 27 July 2006

(C) Springer-Verlag 2006

\begin{abstract}
Pollen, plant macrofossil and charcoal analyses of sediments from two Alaskan lakes provide new data for inferring Lateglacial and Holocene environmental change. The records span the past 14,700 years at Lost Lake, $240 \mathrm{~m}$ a.s.l., central Alaska, north of the Alaska Range and 9600 years at Grizzly Lake, 720 m a.s.l., Copper River Plateau, south of the Alaska Range. Salix shrubs expanded in the herb tundra about 14,400 cal B.P., and Betula shrub tundra became established at ca. 13,200 cal B.P. Diminished Betula shrub cover in association with the increased abundance of herbaceous taxa occurred at 12,500-11,600 cal B.P., although the timing of these changes is not well constrained. Populus expanded at 11,200 cal B.P. and formed dense stands until 9600-9400 cal B.P. when Picea glauca forests or woodlands became established at both sites. The abundance of Alnus viridis increased markedly around 8500 cal B.P. at both sites, marking the development of alder shrub thickets around the lakes and on mountain slopes in these areas. Boreal forests dominated by Picea mariana became established around $7200 \mathrm{cal}$ B.P. at Grizzly Lake and 5700 cal в.P. at Lost Lake. At Grizzly Lake, marked vegetational oscillations occurred within the past 8500 years; for example, $A$. viridis expanded at $2750 \mathrm{cal}$ B.P. and $450 \mathrm{cal}$ B.P. and declined at $150 \mathrm{cal}$ B.P. Some of these oscillations coincide with large-scale climatic events,
\end{abstract}

Communicated by Pim van der Knaap

W. Tinner $(\bowtie) \cdot$ F. S. Hu

Department of Plant Biology, University of Illinois,

505 S. Goodwin Ave, Urbana, IL 61801, USA

e-mail: willy.tinner@ips.unibe.ch

Tel.: +41-31631-4932

Fax: + 41-31631-4942

W. Tinner $\cdot$ R. Beer $\cdot$ P. Kaltenrieder $\cdot$ B. Scheurer Institute of Plant Sciences, University of Bern,

Altenbergrain 21,

3013 Bern, Switzerland

U. Krähenbühl

Department of Chemistry and Biochemistry, University of Bern,

Freiestrasse 3,

3000 Bern 9, Switzerland such as the Little Ice Age cooling (LIA), and they probably reflect vegetational sensitivity to climatic change at this high site. Microscopic charcoal at Lost Lake suggests that fire was important in the lateglacial birch tundra, probably because of severe moisture deficits of the regional climate and/or high abundance of fine fuels. On the basis of the Grizzly Lake microscopic charcoal record, regional fires were common between 8500 and 6800 cal B.P. and between 450 and 150 cal B.P. Around Grizzly Lake, the mean return intervals of local fires estimated from macroscopic charcoal were $\sim 386$ years between 6800 and $5500 \mathrm{cal}$ B.P. when Picea glauca dominated over P. mariana, $\sim 254$ years between 5500 and 3900 cal B.P. when $P$. mariana was more abundant than $P$. glauca, and $\sim 200$ years after 3900 cal B.P. in both $P$. glauca and $P$. mariana dominated forests. Correlation analysis of pollen and microscopic charcoal at Grizzly Lake reveals that increased fire activity led to the reductions of $P$. glauca, $P$. mariana, and tree Betula in association with the expansions of A. viridis, Epilobium, Lycopodium clavatum, and L. annotinum.

Keywords Microscopic charcoal - Macroscopic charcoal · Holocene · Lateglacial · Picea mariana P Picea glauca

\section{Introduction}

During the past decades palynological studies have resulted in a large pollen database from Alaska (e.g. Ager 1975; Anderson et al. 1990; Hu et al. 1993; Anderson and Brubaker 1994). These studies offer important information on late Quaternary vegetational and climatic histories of the region. However, a number of palaeoecological issues remains unresolved. For example, new pollen records with chronologies based on AMS ${ }^{14} \mathrm{C}$ dating of plant macrofossils reveal that vegetational transitions occurred later than previously thought (Bigelow and Edwards 2001). In addition, new palaeoclimatic studies (Hu et al. 2001, 2003; Lynch et al. 2004a) provide compelling evidence of marked climatic change during the middle and late 


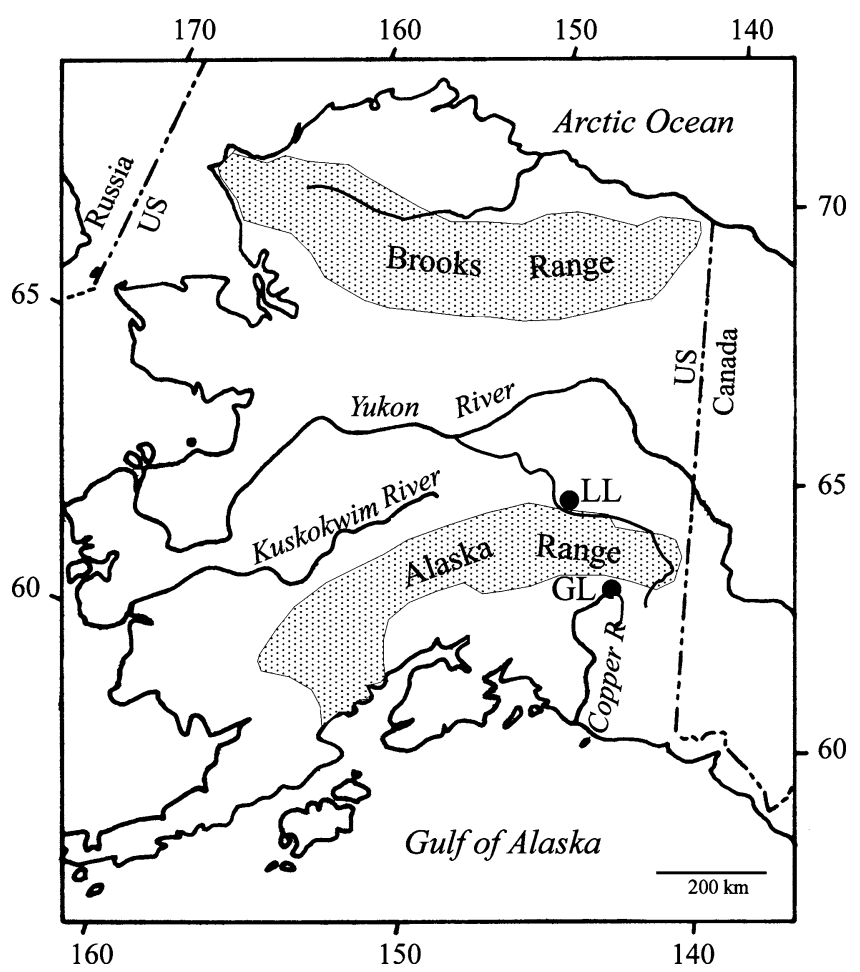

Fig. 1 Map showing the location of the study sites: LL: Lost Lake, GL: Grizzly Lake

Holocene, but existing pollen data do not have the chronological resolution to capture potential vegetational response to this climatic change. Furthermore, it is well known that in the modern landscape, forest fire greatly influences species composition and ecosystem processes, such as energy fluxes and elemental cycles. Although palaeoecologists have speculated that fires were important in shaping Holocene vegetation, only a few fire history records are available from Alaska (Lynch et al. 2002, 2004a; Hu et al. in press). These previous studies of fire history concentrated on the effects of climatic and vegetational change on fire regimes, and the long-term effects of fire on vegetation have not been addressed.

In this paper we first describe vegetational changes during the Lateglacial and the Holocene on the basis of pollen and macrofossil records from Grizzly Lake $\left(62^{\circ} 42^{\prime} 35^{\prime \prime} \mathrm{N}\right.$, $\left.144^{\circ} 11^{\prime} 50^{\prime \prime} \mathrm{W}\right)$ and Lost Lake $\left(64^{\circ} 18^{\prime} 00^{\prime \prime} \mathrm{N}, 146^{\circ} 41^{\prime} 30^{\prime \prime} \mathrm{W}\right)$ in Alaska (Fig. 1). We then reconstruct the fire history on the basis of microscopic and macroscopic charcoal records from the same sites. Finally, we attempt to address climatevegetation-fire linkages at our sites.

\section{Study areas}

Grizzly Lake lies at the northeastern edge of the Copper River Basin, on the southern slope of the Alaska Range at $720 \mathrm{~m}$ a.s.l. It has a surface area of ca. 11 ha and a watershed area of ca. 125 ha. The maximum water depth of the lake was $8.20 \mathrm{~m}$ in July 2000 . Today the lake is a topographically closed basin with no major inlet and outlet. The Grizzly Lake area has a boreal continental climate with marked seasonal temperature variations. In Slana $(730 \mathrm{~m}$ a.s.l., $\sim 10 \mathrm{~km}$ east of Grizzly Lake), the mean July and January temperatures are 13.7 and $-19.1^{\circ} \mathrm{C}$ (period $1961-$ 1990, WorldClimate 2005). The mean annual temperature is $-2.5^{\circ} \mathrm{C}$, and mean annual precipitation $391 \mathrm{~mm}$. On the moraine ridges around the lake and on the mountain slope north of the lake, boreal forests are dominated by Picea glauca (white spruce), with Betula neoalaskana (Alaska birch) and Populus tremuloides (aspen) as common constituents. B. kenaica (Kenai birch) is also found in the region. Plant communities dominated by Picea mariana (black spruce) and Sphagnum species are prevalent in the extensive lowlands of the Copper River Basin. P. mariana forms nearly pure stands on the wet soils of the lowlands south of the lake. Within the region, $P$. glauca forms timberline stands, and this species can reach maximum elevations of 1100-1300 m a.s.l. Locally near Grizzly Lake, the $P$. glauca treeline is at about 900-1000 m a.s.l., and Alnus viridis (green alder) thickets grow up to about $1100 \mathrm{~m}$ a.s.l. On gentle slopes with wet soils, P. mariana extends to the treeline (Viereck and Little 1994). The altitudinal limits of P. mariana and Betula trees (mainly B. neoalaskana, Alaska birch) are at ca. 800-900 m in the study area (Hultén 1968); hence the elevation of Grizzly Lake at $720 \mathrm{~m}$ is not far below the altitudinal limits of these two tree species.

Lost Lake (also known as Chisholm Lake) is located in the Tanana valley north of the Alaska Range at $240 \mathrm{~m}$ a.s.l. The lake has a surface area of ca. 31 ha and a watershed area of ca. 780 ha. Today the lake has an inlet on the east, but no major surface outlet. The Lost Lake area experiences a boreal continental climate, with warmer summers and slightly cooler winters than in the Grizzly Lake area, but with comparable precipitation. At Big Delta (305 m a.s.l., $\sim 5 \mathrm{~km}$ south of Lost Lake), the mean July and January temperatures are 15.6 and $-20.0{ }^{\circ} \mathrm{C}$ (period 1961-1990, WorldClimate, 2005). The mean annual temperature is $-2.3{ }^{\circ} \mathrm{C}$, and mean annual precipitation 304 $\mathrm{mm}$. Lost Lake is surrounded by bedrock ridges to the south, east and north, whereas the west end is formed by a dam of outwash sand and gravel deposited by the Tanana River during the late Pleistocene (Ager 1975). Local boreal forests around Lost Lake are dominated by Picea glauca. Other important forest species are Betula neoalaskana and Populus tremuloides. Closed Picea glauca and Populus balsamifera (balsam poplar) forests occur in the floodplains of the Tanana River, ca. $2 \mathrm{~km}$ southwest of the lake (Ager 1975). In the flatlands south of the Tanana River, where permafrost is usually close to the soil surface, $P$. mariana and Larix laricina (tamarack) are the most common trees. The uppermost treeline positions in the area are at ca. $1000-1200 \mathrm{~m}$ a.s.l., and the treeline is formed by P. glauca.

\section{Material and methods}

Coring

Two parallel short cores (GYG and GYH, $1 \mathrm{~m}$ apart) were taken with plexiglass tubes from the deepest 
Table $1{ }^{210} \mathrm{~Pb}$ and ${ }^{14} \mathrm{C}$ dates from Grizzly Lake

\begin{tabular}{|c|c|c|c|c|c|c|c|}
\hline Lab code & Core & Depth $(\mathrm{cm})$ & Material & ${ }^{210} \mathrm{~Pb}$ (yrs A.D.) & $\begin{array}{l}{ }^{14} \text { C dates } \\
\text { (yrs B.P.) }\end{array}$ & $\begin{array}{l}\text { Cal ages }\left(2 \sigma^{\mathrm{a}}\right) \\
\text { A.D. or B.P. }\end{array}$ & $\begin{array}{l}\text { Age in diagram } \\
\text { (before A.D. 1950) }\end{array}$ \\
\hline Bern & GYG & $0-1$ & Bulk & $1993 \pm 0.3$ & & A.D. 1994-1992 & -44 \\
\hline Bern & GYG & $1-2$ & Bulk & $1980 \pm 2.1$ & & A.D. 1984-1976 & -30 \\
\hline Bern & GYG & $2-3$ & Bulk & $1972 \pm 2.3$ & & A.D. $1977-1967$ & -22 \\
\hline Bern & GYG & $3-4$ & Bulk & $1963 \pm 2.3$ & & A.D. $1968-1958$ & -13 \\
\hline Bern & GYG & $4-5$ & Bulk & $1937 \pm 6.1$ & & A.D. 1949-1925 & 13 \\
\hline Bern & GYG & $5-6$ & Bulk & $1899 \pm 12.9$ & & A.D. $1925-1873$ & 51 \\
\hline Ua-19438 b & GYG & $14-15$ & $\mathrm{P}$, Picea $\mathrm{N}$ & & $485 \pm 45^{\mathrm{b}}$ & $465-631^{b}$ & 241 \\
\hline Ua-19439 & GYG & $18-19$ & $\begin{array}{l}\mathrm{P}, \text { Picea } \mathrm{N}, \text { Betula } \mathrm{F} \\
\text { Ledum L }\end{array}$ & & $330 \pm 35$ & $307-479$ & 325 \\
\hline Ua-19440 & GYG & $19-20$ & Picea $\mathrm{N}$, Betula $\mathrm{F}, \mathrm{P}$ & & $290 \pm 40$ & $155-467$ & 347 \\
\hline CAMS-84953 & GYG & $21-22$ & $\mathrm{P}, \mathrm{T}, \mathrm{W}$ & & $305 \pm 40$ & $292-476$ & 364 \\
\hline CAMS-66875 & GYA & $33-35$ & W & & $360 \pm 50$ & $311-501$ & 422 \\
\hline CAMS-84955 & GYH & $43-47$ & $\mathrm{P}, \mathrm{C}, \mathrm{T}, \mathrm{W}$ Betula $\mathrm{F}$ & & $385 \pm 40$ & $316-511$ & 492 \\
\hline CAMS-66876 & GYA & $73-75$ & $\mathrm{~T}$ & & $1770 \pm 50$ & $1564-1819$ & 1672 \\
\hline Ua-20497 & GYE & $75-79$ & $\mathrm{P}, \mathrm{L}$, Alnus FS, F, & & $1865 \pm 45$ & $1701-1917$ & 1821 \\
\hline Poz-6496 & GYF & 91 & & & $2520 \pm 30$ & $2488-2741$ & 2651 \\
\hline Ua-20498 & GYE & $118-125$ & $\mathrm{P}$, Betula F, Picea N & & $3815 \pm 70$ & $3990-4417$ & 4187 \\
\hline CAMS-59343 & GYA & $131-132$ & Picea $\mathrm{T}$ & & $4170 \pm 40$ & $4577-4835$ & 4713 \\
\hline CAMS-82320 & GYE & $133-134$ & Picea $\mathrm{N}$ & & $4225 \pm 40$ & $4626-4858$ & 4792 \\
\hline CAMS-82321 & GYE & $133-134$ & wood & & $4800 \pm 45^{\mathrm{b}}$ & $5331-5609^{\mathrm{b}}$ & 4792 \\
\hline CAMS-82322 & GYE & $133-134$ & Picea CS & & $4125 \pm 35$ & $4528-4820$ & 4792 \\
\hline CAMS-82323 & GYE & $133-134$ & $\mathrm{C}$ & & $4955 \pm 40^{\mathrm{b}}$ & $5598-5853^{\mathrm{b}}$ & 4792 \\
\hline CAMS-82324 & GYE & $133-134$ & $\mathrm{P}$ & & $4180 \pm 40$ & $4581-4769$ & 4792 \\
\hline CAMS-82325 & GYE & $133-134$ & $\mathrm{P}$ & & $4190 \pm 40$ & $4583-4843$ & 4792 \\
\hline CAMS-82326 & GYE & $133-134$ & M & & $4160 \pm 40$ & $4571-4831$ & 4792 \\
\hline CAMS-59342 & GYA & 193-194 & $\begin{array}{l}\mathrm{L}, \text { Vaccinium L, } \\
\text { Picea N, CS, } \\
\text { Populus L, }\end{array}$ & & $6070 \pm 50$ & $6788-7156$ & 6864 \\
\hline CAMS-59339 & GYA & $292-293$ & $\mathrm{~W}$ & & $7100 \pm 50$ & $7835-8013$ & 7806 \\
\hline CAMS-59340 & GYA & $292-293$ & W & & $6910 \pm 40$ & $7671-7833$ & 7806 \\
\hline CAMS-59341 & GYA & $292-293$ & $\mathrm{C}$ & & $7430 \pm 50^{\mathrm{b}}$ & $8171-8367^{\mathrm{b}}$ & 7806 \\
\hline CAMS-66877 & GYB & $351-353$ & $\mathrm{~T}$ & & $7710 \pm 40$ & $8415-8581$ & 8459 \\
\hline CAMS-59338 & GYA & 381 & Picea CS & & $8150 \pm 50$ & 9004-9257 & 9061 \\
\hline
\end{tabular}

${ }^{a}$ calibration of radiocarbon dates: Calib 5.01 (Stuiver and Reimer 1993; Reimer et al. 2004)

${ }^{b}$ Rejected date; C: charcoal, CS: cone scales, F: fruits, FS: fruit scales, L: leaves, M: mosses, N: needles, P: periderm, T: twig, W: wood

part of Grizzly Lake. Core GYG contained an intact sediment-water interface. For older sediments, long cores (including GYA, GYB, GYE, and GYF, see Table 1) were taken with a modified Livingstone piston corer (Wright et al. 1984). The cores were correlated according to lithostratigraphy, and the correlation precision among the different cores of Grizzly Lake is ca. $\pm 1 \mathrm{~cm}$ of depth. The core of Lost Lake (LL97B) was retrieved with a modified Livingstone piston corer from the deepest part of the lake.

\section{Dating}

The age of the surface sediments of Grizzly Lake (core GYG) was estimated with ${ }^{210} \mathrm{~Pb}$-dating. Bulk-sediment samples for ${ }^{210} \mathrm{~Pb}$ dating (Table 1), each containing about $2 \mathrm{~g}$ of dry material, were measured with an HPGe detector for several days. From the measured count-rates the corresponding absolute activities and their errors were reduced in order to correct for the absolute decay-branch of the $46.5 \mathrm{keV} \gamma$-line of $4 \%$, the detector efficiency, and counting statistics (Gäggeler et al. 1976). The decreasing specific ${ }^{210} \mathrm{~Pb}$ activities (in $\mathrm{Bq} / \mathrm{g}$ ) with increasing depth permitted estimates of the absolute age relative to the surface of the core.

AMS (Accelerated Mass Spectrometry) ${ }^{14} \mathrm{C}$ ages were obtained from 24 and five terrestrial plant macrofossils from the sediments of Grizzly and Lost Lakes, respectively (Tables 1 and 2). Macrofossils from the Grizzly Lake sediments were used in a study into the effects of the types and amounts of plant macrofossils on ${ }^{14} \mathrm{C}$ chronologies 


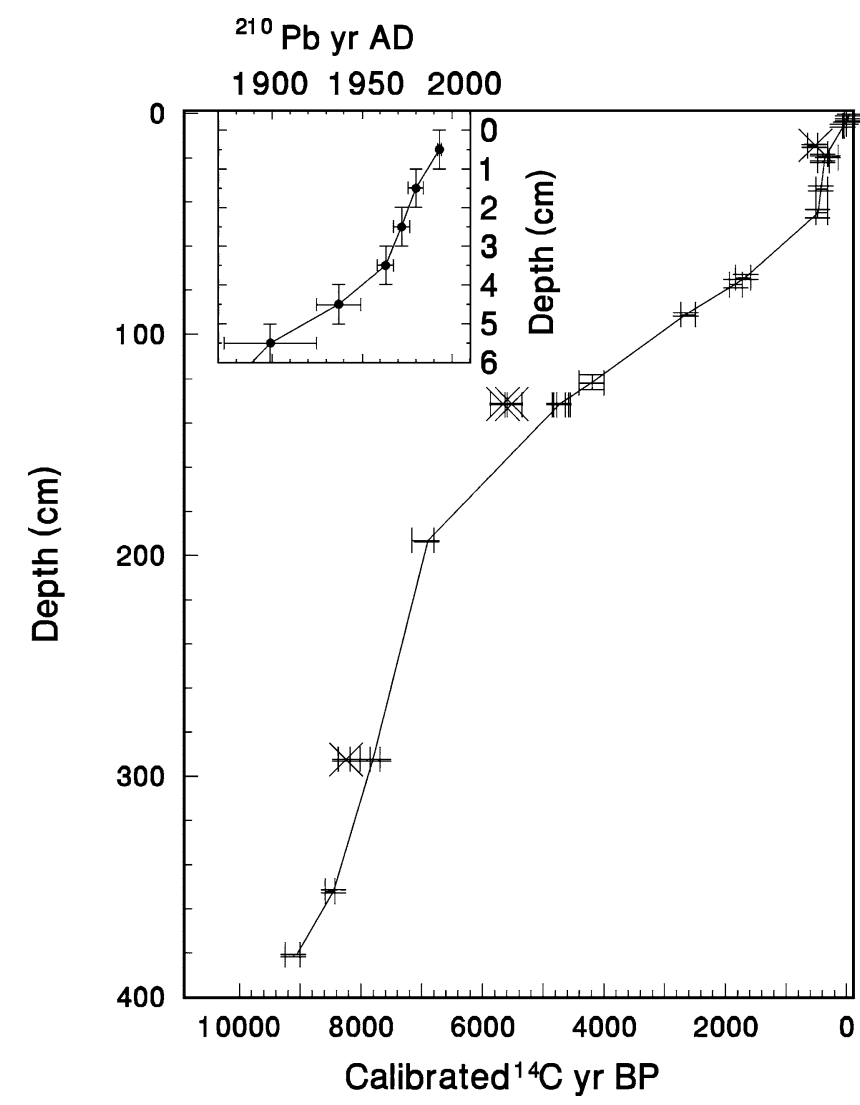

Fig. 2 Depth-age model of Grizzly Lake

(Oswald et al. 2005). The ${ }^{14} \mathrm{C}$ dates were converted to calibrated ages (cal B.P.) with the program Calib version 5.0.1 (Stuiver and Reimer 1993; Reimer et al. 2004). The age-depth models were based on linear interpolation of the mean values of calibrated ${ }^{14} \mathrm{C}$ dates. Three neighbouring ages of core GYG (Table 1, 18-19, 19-20, 21-22 cm) were amalgamated (OxCal 3.5, Ramsey 2001) and connected with linear interpolation to the oldest ${ }^{210} \mathrm{~Pb}$ date and the subjacent A.D. ages (Fig. 2). Similarly we pooled groups of ages for the same depths (e.g. GYE 133-134 cm, Table 1).

\section{Pollen and microscopic charcoal analysis}

Pollen preparation followed standard procedures for glycerine samples (Moore et al. 1991). Lycopodium tablets (Stockmarr 1971) were added to subsamples of $1 \mathrm{~cm}^{3}$ for estimating pollen concentrations (grains $\mathrm{cm}^{-3}$ ) and accumulation rates (grains $\mathrm{cm}^{-2} \mathrm{yr}^{-1}$ ). Nomenclature of plant taxa follows that of the Flora of North America (FNA, 2005). Pollen type separation followed Clegg et al. (2005) for Betula, Hansen (unpublished) for Picea, and Punt et al. (2005) for Alnus. A minimum of 600 pollen grains, excluding aquatic pollen and spores, were counted at each level except at several levels where pollen concentrations were extremely low. The pollen diagrams were subdivided into local pollen assemblage zones (LPAZ) by us- ing the zonation method of optimal partitioning (Birks and Gordon 1985) as implemented in the program ZONE, version 1.2, written by Steve Juggins. To determine the number of statistically significant zones in diagrams, we used the program BSTICK (Bennett 1996). At both sites the divisions of subzones (GY-1a, GY1b, GY-3a, GY-3b, and GY-3c for Grizzly Lake, and LL5a, LL5b, LL4a, LL4b, and LL4c for Lost Lake) are based on the results of ZONE analysis, but they are statistically insignificant.

Microscopic charcoal particles longer than $10 \mu \mathrm{m}$ (or area $>75 \mu \mathrm{m}^{2}$ ) were counted in pollen slides following Tinner and $\mathrm{Hu}$ (2003) and Finsinger and Tinner (2005). Charcoal number concentration (particles $\mathrm{cm}^{-3}$ ) and influx (particles $\mathrm{cm}^{-2} \mathrm{yr}^{-1}$ ) were estimated by using the same approach as for pollen (Stockmarr 1971). Mean sampling resolution for pollen and microscopic charcoal was $3 \mathrm{~cm}$ (corresponding to $70 \mathrm{yr}$ ) at Grizzly Lake and $7 \mathrm{~cm}$ (corresponding to $215 \mathrm{yr}$ ) at Lost Lake. Unfortunately, it is not possible to quantitatively estimate regional fire frequencies without contiguous sampling and without a calibration set comparing modern regional fire frequencies and the microscopic charcoal influx in surface sediments (Tinner et al. 1998).

Macrofossil analysis and MFI estimation

For the analyses of macroscopic charcoal and terrestrial macrofossils at Grizzly Lake, sediment samples of $18 \mathrm{~cm}^{3}$ $(0-50 \mathrm{~cm})$ or $36 \mathrm{~cm}^{3}(50-190 \mathrm{~cm})$ were washed on a $200 \mu \mathrm{m}$ mesh sieve, and macrofossils were identified following standard keys, for example Lévesque et al. (1988), and reference specimens. We distinguished tree versus shrub types of Betula macrofossils, but did not attempt to identify them to species level with the exception of $B$. nana. The macrofossil diagram shows numbers, for example, of needles, seeds, fruits, leaves, and areas, for example, of bark, wood, and charcoal, of macrofossils per volume of sediment (standardized to $20 \mathrm{~cm}^{3}$ ). Areas were measured by fine-grid graph paper under a microscope. Macrofossil and macro-charcoal analyses were done on contiguous $1 \mathrm{~cm}$ subsamples, equivalent to 36 years on average. These analyses were restricted to the depths $0-190 \mathrm{~cm}(6800 \mathrm{cal}$ B.P. to A.D. 2000) because it was not possible to penetrate through the silt layers with the large-diameter coring tubes used to retrieve the cores for macrofossil analysis (GYE and GYF).

In order to eliminate the effect of secondary charcoal, the raw data of macroscopic charcoal influx $\left(\mathrm{mm}^{2} \mathrm{~cm}^{-2}\right.$ $\mathrm{yr}^{-1}$ ) was smoothed with a bandwidth of 100 years, using a weighted average function. This smoothed background was subtracted from the raw data to derive residual peaks. We then examined the statistical distribution of residuals and estimated the proportion of peak accumulation values above a threshold value P (Lynch et al. 2002). A sensitivity analysis was used to identify how the proportion of peak accumulation rates changes with $P$. This analysis was used to identify an intermediate range of charcoal accumulation rates between background and the largest peak values 
(Clark et al. 1996; Lynch et al. 2002). We assumed that local fire events were represented by the range of charcoal accumulation rates within which the mean intervals in years between peak values were relatively insensitive to changes in P. This analysis identified the upper $14 \%$ of residual distribution, with charcoal peaks $>0.003 \mathrm{~mm}^{2} \mathrm{~cm}^{-2} \mathrm{yr}^{-1}$, as local fire events. The fire return interval is the time between two adjacent events, and the mean fire return interval (MFI) within a period was the average of all fire return intervals of that period. Explorative analyses showed that MFI estimates were similar when a smoother of 600-yr bandwidth (Whitlock and Larsen 2001) was used instead of a 100-yr bandwidth, if all residual peaks identified by the stronger smoother were considered for MFI estimation.

\section{Correlation analysis}

To investigate whether microscopic charcoal and pollen are significantly related to each other, we calculated correlation coefficients ( $r$ values) and applied a $t$-test to determine whether the $r$ values were significantly different from 0 $(r \neq 0, \alpha=5 \%$, two-sided, Bahrenberg et al. 1985). The period 9000 cal B.P.-A.D. 2000) was selected for this analysis because boreal vegetation existed at both sites. Before 9500-9000 cal. B.P. the vegetation differed from that of modern Alaskan taiga in both areas, with Populus, Betula shrubs, and Salix as the most important constituents.

\section{Results}

Chronology and lithology

At Grizzly Lake, three ${ }^{14} \mathrm{C}$ dates appeared too old when compared with neighbouring dates and were rejected (Table 1, Fig. 2). At Lost Lake all dates were accepted (Table 2, Fig. 3). The sediments are gyttja from 0 to ca. $190 \mathrm{~cm}$ (0-6900 cal в.P.) at Grizzly Lake and 0 to ca. $320 \mathrm{~cm}(0$ 12,400 cal B.P.) at Lost Lake (Figs. 4 and 5). The lower sediments at Grizzly Lake are mainly silty material with minor gyttja layers (Fig. 4).

Pollen

Pollen percentage, concentration, and influx values are comparable at each of the two sites, and we therefore use the percentage results. The Lateglacial and early Holocene period before 9600 cal B.P. is recorded only at Lost Lake. Pollen assemblages in the oldest section (LPAZ LL-1 and LL-2; ca. 14,600-14,400 cal B.P.) are dominated by herbaceous taxa such as Poaceae, Cyperaceae and Artemisia. In zone LL-3 (14,400-13,200 cal B.P.) Salix pollen percentages increase (Fig. 5) to reach a peak at ca. 13,400 cal B.P.

LL-4 (13,200-8500 cal B.P.) is a rather long and heterogeneous pollen zone. It is therefore subdivided into three subzones. In LL-4a (13,200-11,200 cal B.P.), a prominent rise of shrub Betula pollen is accompanied by a decline of pollen of many herbaceous taxa such as Artemisia, Asteroideae and Bupleurum). Pollen of shrub Betula decreases at 12,500-11,600 cal B.P., when pollen of herbaceous taxa such as Artemisia and Poaceae increases. The first tree taxon to reach high pollen values is Populus at the beginning of the Holocene (LL-4b, ca. 11,200-9700 cal B.P.). The end of this Populus period, which is accompanied by the rise of $P$. glauca t., is also documented at Grizzly Lake near the base of the sediment core (LPAZ GY-1a, ca. 9600-9400 cal в.P.).

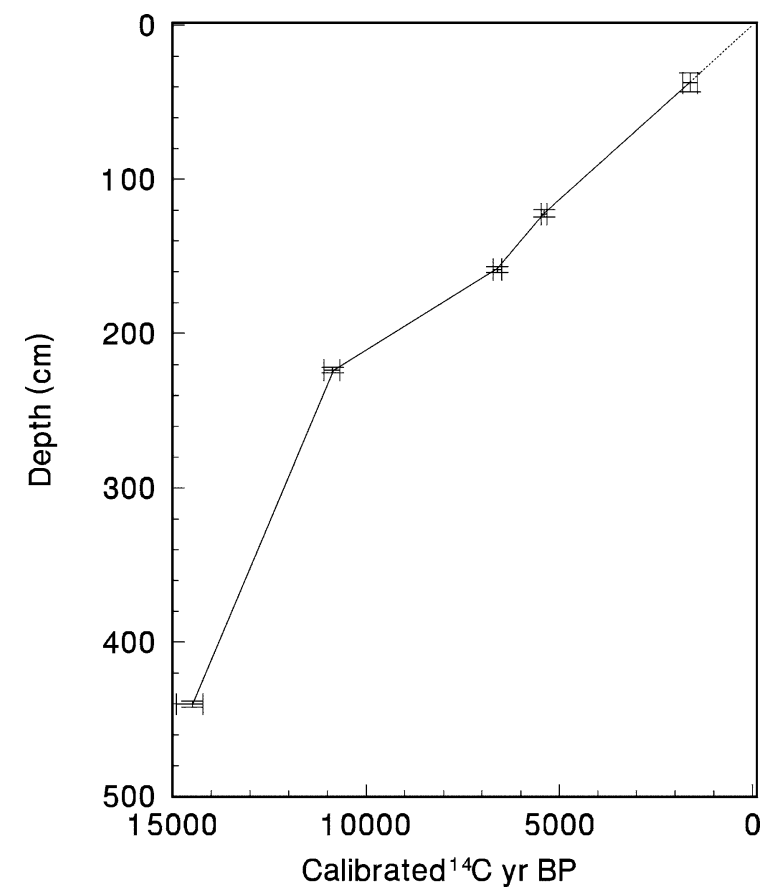

Fig. 3 Depth-age model of Lost Lake
Table $2{ }^{14} \mathrm{C}$ dates from Lost Lake; further explanations see Table 1

\begin{tabular}{|c|c|c|c|c|c|c|}
\hline Lab code & Core & $\begin{array}{l}\text { Depth } \\
(\mathrm{cm})\end{array}$ & Material & $\begin{array}{l}{ }^{14} \mathrm{C} \text { dates } \\
\text { (yrs B.P.) }\end{array}$ & $\begin{array}{l}\text { Cal B.P. } \\
(2 \sigma *)\end{array}$ & $\begin{array}{l}\text { Age in diagram } \\
\text { (before A.D. 1950) }\end{array}$ \\
\hline CAMS-68678 & LL97B & $31-43$ & $\begin{array}{l}\mathrm{P}, \mathrm{L}, \text { Betula } \\
\text { (tree) F, } \\
\text { Alnus }\end{array}$ & $1710 \pm 60$ & $1422-1812$ & 1621 \\
\hline CAMS-68677 & LL97B & $120-124$ & $\mathrm{~W}, \mathrm{~T}$ & $4670 \pm 40$ & $5312-5475$ & 5395 \\
\hline CAMS-68676 & LL97B & $156-160$ & $\mathrm{~T}, \mathrm{P}$ & $5800 \pm 40$ & $6492-6717$ & 6607 \\
\hline CAMS-68675 & LL97B & $222-226$ & $\mathrm{~W}, \mathrm{P}$ & $9530 \pm 50$ & $10682-11091$ & 10845 \\
\hline CAMS-68674 & LL97B & $438-442$ & Potentilla $\mathrm{S}$ & $12460 \pm 50$ & $14204-14893$ & 14482 \\
\hline
\end{tabular}




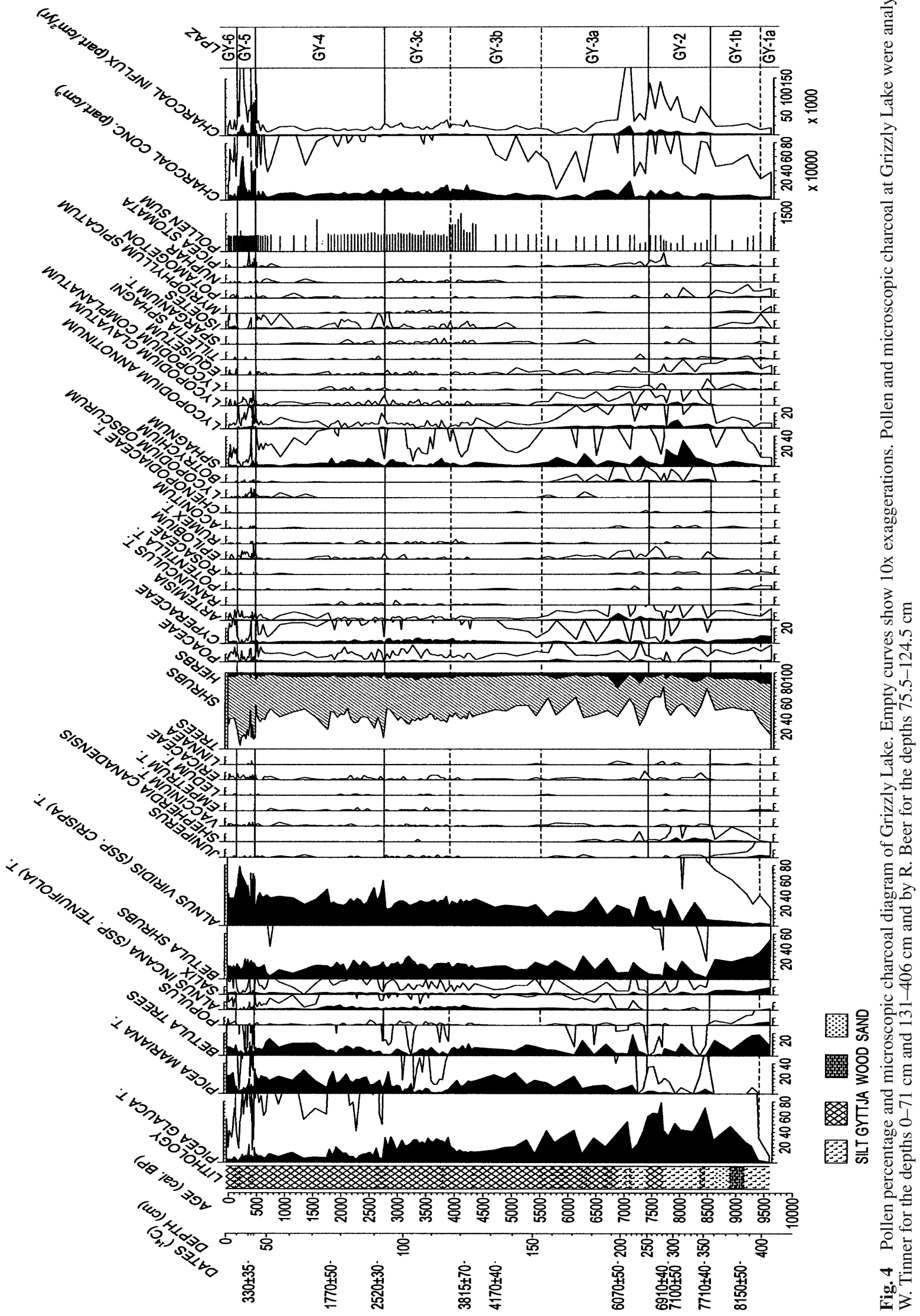




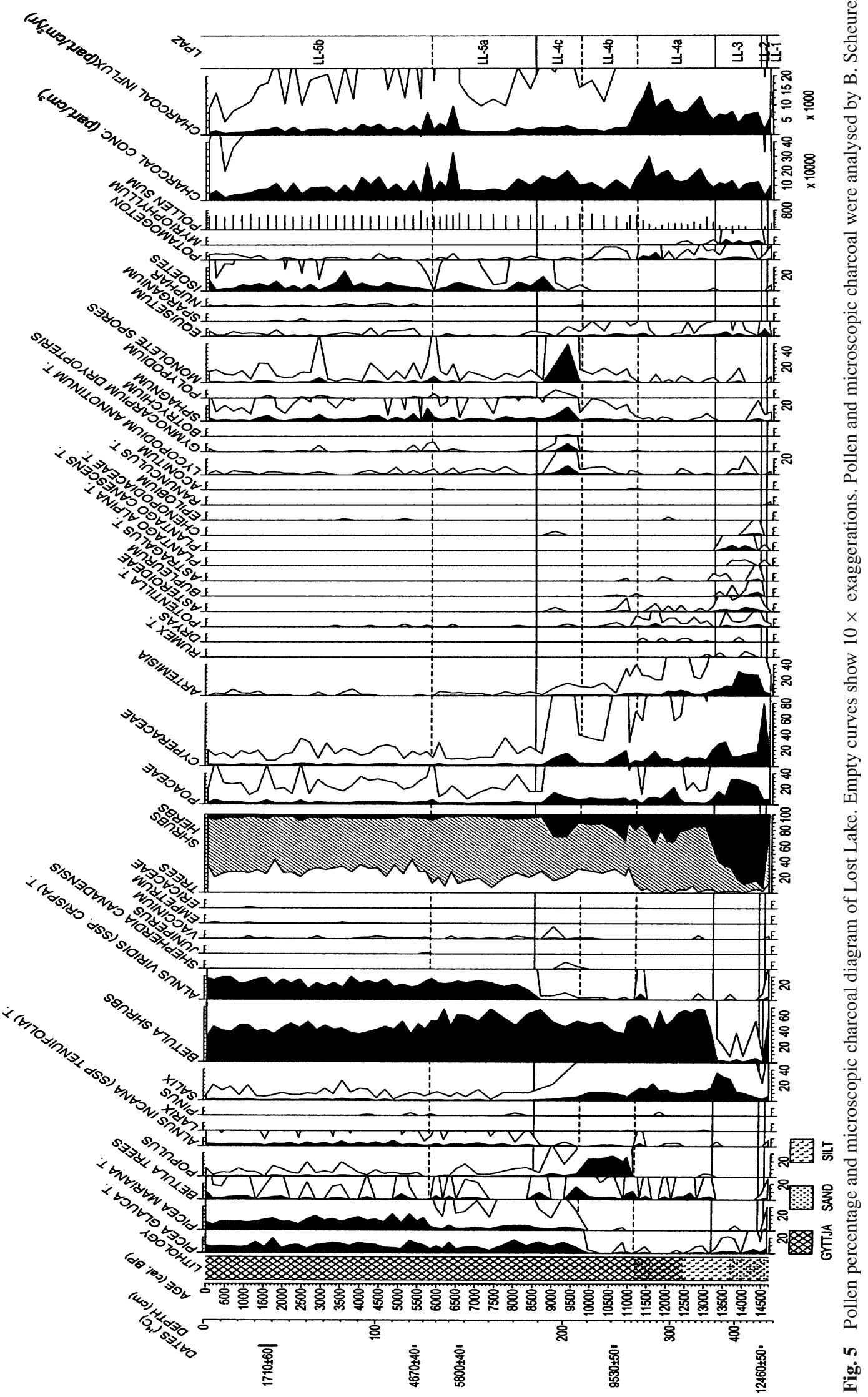


The subsequent pollen stratigraphies have similar characteristics between Grizzly and Lost Lakes. Between 9500 and 8400 cal B.P. (GY1b and LL-4c) the dominant pollen types are Picea glauca t. and Betula. Pollen of Betula shrubs is more abundant at Lost Lake than at Grizzly Lake throughout the entire Holocene. Statistically, the most marked change after 9700-9400 cal B.P. (Populus decline) occurs at ca. 8500 cal B.P. (GY-1 to 2; LL-4 to 5, Figs. 4 and 5) when pollen percentages of Alnus viridis increase at both sites. This change is accompanied by a more gradual increase of Picea mariana t., reaching maximum values at both sites (zone boundaries GY-3a to GY-3b and LL-5a to LL-5b, Figs. 4 and 5) around 5500 cal. B.P. when $P$. glauca t. declines at Grizzly Lake but not at Lost Lake. The pollen spectra do not vary greatly after 8500 cal B.P. at Lost Lake, with the co-dominance of shrub Betula, P. mariana t., P. glauca t., and Alnus viridis (LL-5). In contrast, major pollen assemblage changes occur at Grizzly Lake during the same period, as suggested by four statistically significant pollen zone boundaries at 7400, 2750, 450, and 150 cal B.P. These zone boundaries all coincide with marked variations in Alnus viridis pollen percentages.

In GY-2 (8500-7400 cal B.P.) pollen percentages of $\mathrm{Al}$ $n u s$ viridis increase and $P$. glauca t. pollen is abundant at Grizzly Lake, reaching maximum values of ca. $80 \%$. During the same period, $P$. glauca $\mathrm{t}$. pollen reaches maximum percentages also at Lost Lake, but there it never exceeds $20 \%$. This high abundance of $P$. glauca t. at Grizzly Lake is associated with a maximum of Shepherdia canadensis and a major decrease in the pollen percentages of shrub $\mathrm{Be}$ tula and Salix (Fig. 4, GY-2). Pollen percentages of Picea mariana t. are low (with a mean of $2 \%$ ) in this zone, but they increase substantially at the beginning of LPAZ GY-3 (7400-2750 cal в.P.). The pollen spectra of GY-3 are dominated by $P$. glauca t., P. mariana t., A. viridis, and Betula (trees and shrubs). These spectra are similar to those of the same period at Lost Lake, although greater variations occur at Grizzly Lake. These variations define the three subzones GY-3a, GY-3b, and GY-3c, which are characterized mainly by the opposite stratigraphic patterns of $P$. glauca t. and P. mariana t. In GY-3a (7400-5500 cal B.P.) and GY-3c (3900-2750 cal B.P.) P. glauca t. is more abundant than P. mariana $\mathrm{t}$., whereas between these two zones (GY-3b, 5500-3900 cal B.P.) the latter taxon is more prominent.

Pollen percentages of $A$. viridis increase abruptly at Grizzly Lake at the beginning of zone GY-4 (2750-450 cal B.P.). This change is accompanied by an increase of $P$. mariana $t$. and Betula tree type as well as a decrease of P. glauca t. A further increase of $A$. viridis occurs at the transition to GY-5 (450 cal B.P.), when all other tree and shrub pollen types with the exception of Betula shrub type decline (Fig. 4). In GY-6 (150 cal B.P. to present), pollen assemblages of Grizzly Lake are similar to those before 450 cal в.P.

\section{Macrofossils, macroscopic charcoal, and MFI}

High plant debris accumulation occurs at $4800-4400 \mathrm{cal}$ B.P. and 450-300 cal B.P. (Fig. 6). In the macrofossil record,
Picea is important throughout the period (many needle and periderm finds, Fig. 6). Fruit scales and fruits of Betula trees and shrubs are occasionally present. In one case it was possible to determine the presence of $B$. nana fruits. Fruit scales and fruits of Alnus viridis (ssp. crispa), as well as seeds of herbs such as Rubus and the aquatic plants Nuphar polysepalum and Potamogeton occur regularly throughout the record. Sphagnum reaches conspicuous mean concentrations of 10 leaves $20 \mathrm{~cm}^{-3}$ (Fig. 6), which is in good agreement with the microscopic spore record in the pollen diagram (Fig. 4).

Macroscopic charcoal and plant macrofossil concentrations display moderate correlation. For instance, the curves of charred and uncharred Picea needles resemble each other, and the two periods of high plant debris accumulation (4800-4400 cal B.P. and 450-300 cal B.P.) are also mirrored in the total macroscopic charcoal concentration and influx record (Fig. 6). The smoothing of the charcoal curve reduces the influence of these high background values, which probably resulted from increased secondary (charcoal) deposition. The residual macroscopic charcoal peaks show a rather even distribution over the past ca. 7000 years (Fig. 7), with no pronounced increasing or decreasing trends. The MFI is $261 \mathrm{yr}$ for the period $6800 \mathrm{cal}$ B.P. to A.D. 2000. To assess the potential effects of vegetational composition on fire occurrence (Hu et al. 1993; Lynch et al. 2002), we divided the macro-charcoal record into four periods based on the relative abundance of $P$. glauca and P. mariana and calculated the MFI value of each period (Table 3 ). The longest MFI of the entire record is $\sim 386$ years between 6800 and 5500 cal B.P. when $P$. glauca dominated over P. mariana. MFI then decreased to $254 \pm 170$ years between 5500 and 3900 cal B.P. when P. mariana was more abundant than P. glauca. MFI was the lowest (ca. 200 $\pm 50-100$ years) after 3900 cal B.P., and no change in MFI was detected when pollen indicates a dominance shift from $P$. glauca to P. mariana around $2750 \mathrm{cal}$ B.P.

\section{Microscopic charcoal}

At Lost Lake the microscopic charcoal concentrations reach a maximum of 328,727 particles $\mathrm{cm}^{-3}$ (or $87.5 \mathrm{~mm}^{2} \mathrm{~cm}^{-3}$ using the equation of Tinner and $\mathrm{Hu}$ 2003) at ca. $6300 \mathrm{cal}$ B.P. High levels of microscopic

Table 3 MFI (mean fire return interval) and vegetation type at Grizzly Lake; NA: non applicable, too low numbers

\begin{tabular}{llll}
\hline $\begin{array}{l}\text { Vegetation type: } \\
\text { dominant } \text { Picea } \\
\text { species in pollen }\end{array}$ & Period (cal yr B.P.) & MFI (yr) & MFI std. dev \\
record & & & \\
\hline Picea mariana & -50 to 2750 & 203 & 91 \\
Picea glauca & 2750 to 3900 & 201 & 41 \\
Picea mariana & 3900 to 5500 & 254 & 170 \\
Picea glauca & 5500 to 6800 & 386 & NA \\
Complete record & -50 to 6800 & 261 & 161 \\
\hline
\end{tabular}




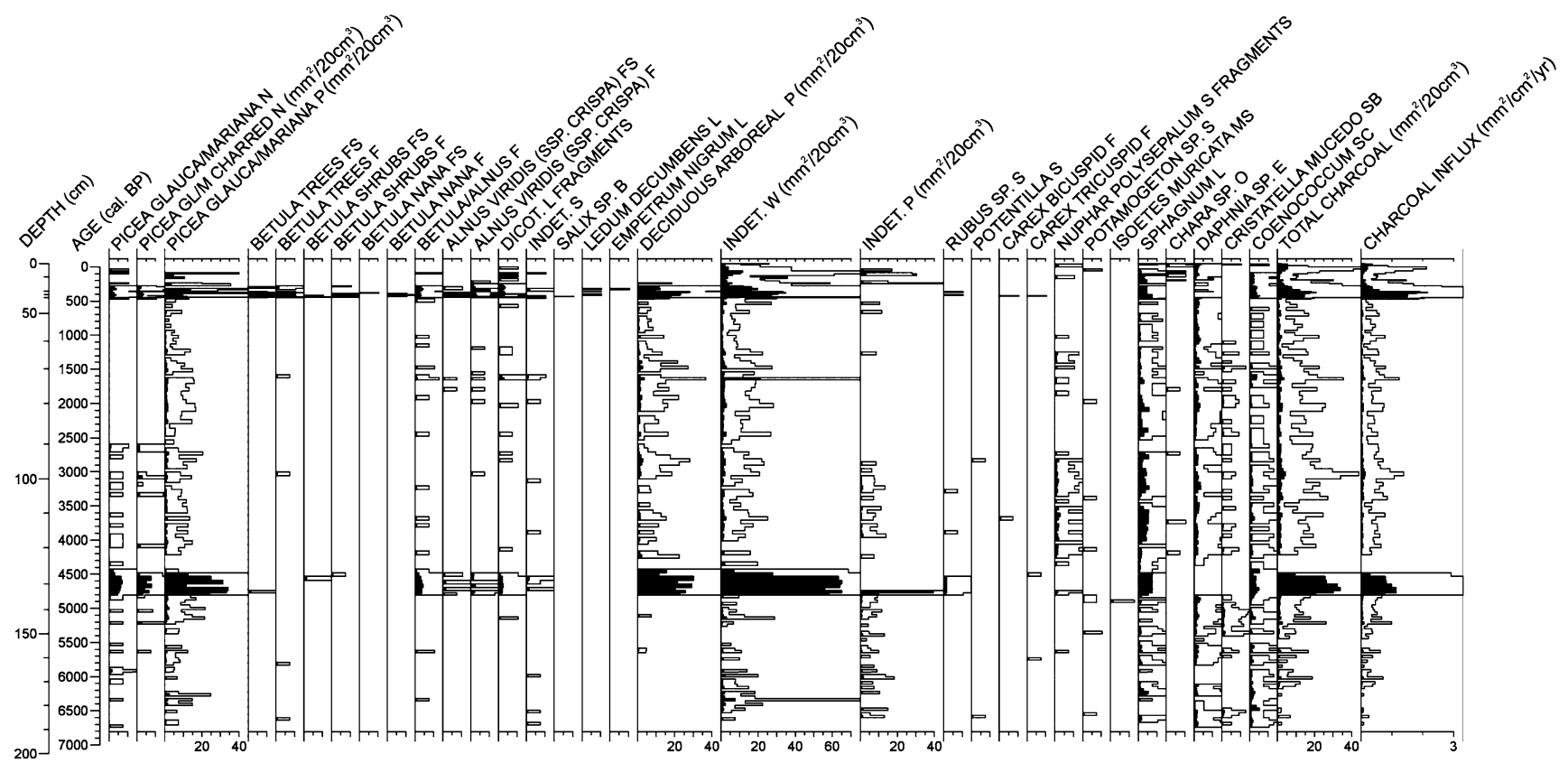

Fig. 6 Macrofossil concentration diagram of Grizzly Lake. All values are square root transformed for better depiction of minor fluctuations. Empty curves show 10x exaggerations. B: buds, E: ephippia, F: fruit, FS: fruit scales, L: leaves, MS: macrospores, N: needles,

O: oogonia, P: periderm, S: seeds, SB: statoblasts, SC: sclerotia, W: wood. Macrofossils and macroscopic charcoal was analysed by $\mathrm{P}$. Kaltenrieder charcoal concentrations also occur around 5700 (256,295 particles $\mathrm{cm}^{-3}$ or $\left.69.3 \mathrm{~mm}^{2} \mathrm{~cm}^{-3}\right), 9300(201,375$ particles $\mathrm{cm}^{-3}$ or $\left.55.3 \mathrm{~mm}^{2} \mathrm{~cm}^{-3}\right)$, and 11,450 cal B.P. $(300,720$ particles $\mathrm{cm}^{-3}$ or $80.5 \mathrm{~mm}^{2} \mathrm{~cm}^{-3}$ ). Before $10,700 \mathrm{cal}$ B.P. the microscopic charcoal influx curve of Lost Lake is tentative because of major sedimentological changes that are not well ${ }^{14} \mathrm{C}$ dated. It is conceivable that the charcoal influx peaks between ca. 12,500 and 11,300 cal B.P. are inflated by (undated) slower sediment accumulation rates (gyttja instead of silt). During the Holocene, microscopic charcoal influx reaches maximum values of 9764 particles $\mathrm{cm}^{-2}$ $\mathrm{yr}^{-1}$ or $3.3 \mathrm{~mm}^{2} \mathrm{~cm}^{-2} \mathrm{yr}^{-1}$ around $6300 \mathrm{cal}$ B.P.

At Grizzly Lake, microscopic charcoal concentrations reach maximum values at $200 \mathrm{cal}$ B.P. $(614,296$ particles $\mathrm{cm}^{-3}$ or $\left.157.1 \mathrm{~mm}^{2} \mathrm{~cm}^{-3}\right)$ and $7050 \mathrm{cal}$ B.P. $(258,365$ particles $\mathrm{cm}^{-3}$ or $69.8 \mathrm{~mm}^{2} \mathrm{~cm}^{-3}$ ). These peak values fall into periods with generally high microscopic charcoal values from 150 to $450 \mathrm{cal}$ B.P. and from 7100 to $6300 \mathrm{cal}$ в.P. (Fig. 4). The corresponding microscopic charcoal influx peaks attain 93,762 particles $\mathrm{cm}^{-2} \mathrm{yr}^{-1}$ (or $27.1 \mathrm{~mm}^{2} \mathrm{~cm}^{-2}$ $\mathrm{yr}^{-1}$ ) at $400 \mathrm{cal}$ B.P. and 24,507 particles $\mathrm{cm}^{-2} \mathrm{yr}^{-1}$ (or $7.7 \mathrm{~mm}^{2} \mathrm{~cm}^{-2} \mathrm{yr}^{-1}$ ) at $7050 \mathrm{cal}$ B.P. In addition, moderately high microscopic charcoal accumulation rates occur between 8400 and $7400 \mathrm{cal}$ B.P. (corresponding to LPAZ GY-2 with the dominance of $P$. glauca t.; Fig. 4). On average, charcoal influx values for the period 9500-0 cal в.P. are more variable and about five times higher at Grizzly Lake $\left(\right.$ mean $=12,188, \mathrm{SD}=22,670$ particles $\mathrm{cm}^{-2} \mathrm{yr}^{-1}$ or mean $=4.0, \mathrm{SD}=7.2 \mathrm{~mm}^{2} \mathrm{~cm}^{-2} \mathrm{yr}^{-1}$ ) than at Lost Lake $\left(\right.$ mean $=2190, \mathrm{SD}=1728$ particles $\mathrm{cm}^{-2} \mathrm{yr}^{-1}$ or mean $=0.8, \mathrm{SD}=0.6 \mathrm{~mm}^{2} \mathrm{~cm}^{-2} \mathrm{yr}^{-1}$ ).

\section{Correlation analysis}

Several pollen types are significantly correlated with microscopic charcoal influx at Grizzly Lake between 9000 cal B.P. and A.D. 2000 (Fig. 8). The correlation coefficients are significantly positive for Alnus viridis, Epilobium, Lycopodium clavatum, and L. annotinum, and negative for Cyperaceae, Poaceae, Salix, Populus, Picea mariana t., and $P$. glauca t. In agreement, the sum of shrubs (which is dominated by A. viridis and Betula) is positively correlated with charcoal, whereas the sums of trees and herbs show significant negative correlation coefficients (Fig. 8). At Lost Lake the positive correlation coefficient for $P$. glauca slightly exceeds the significance limit, and none of the other pollen types shows significant correlation with microscopic charcoal.

\section{Discussion}

Vegetational and climatic changes

In the Lost Lake area, herb tundra with Poaceae, Cyperaceae, and Artemisia as dominant taxa prevailed on the landscape before ca. 14,400 cal B.P. Salix became a dominant component of the herb tundra at ca. $14,400 \mathrm{cal}$ B.P. When Betula shrubs expanded on the tundra around 13,200 cal B.P., many herbaceous taxa such as Artemisia and Asteroideae decreased in abundance. These patterns are broadly consistent with previous studies in central Alaska (Ager 1975; Anderson et al. 1990; Hu et al. 1993; Bigelow and 

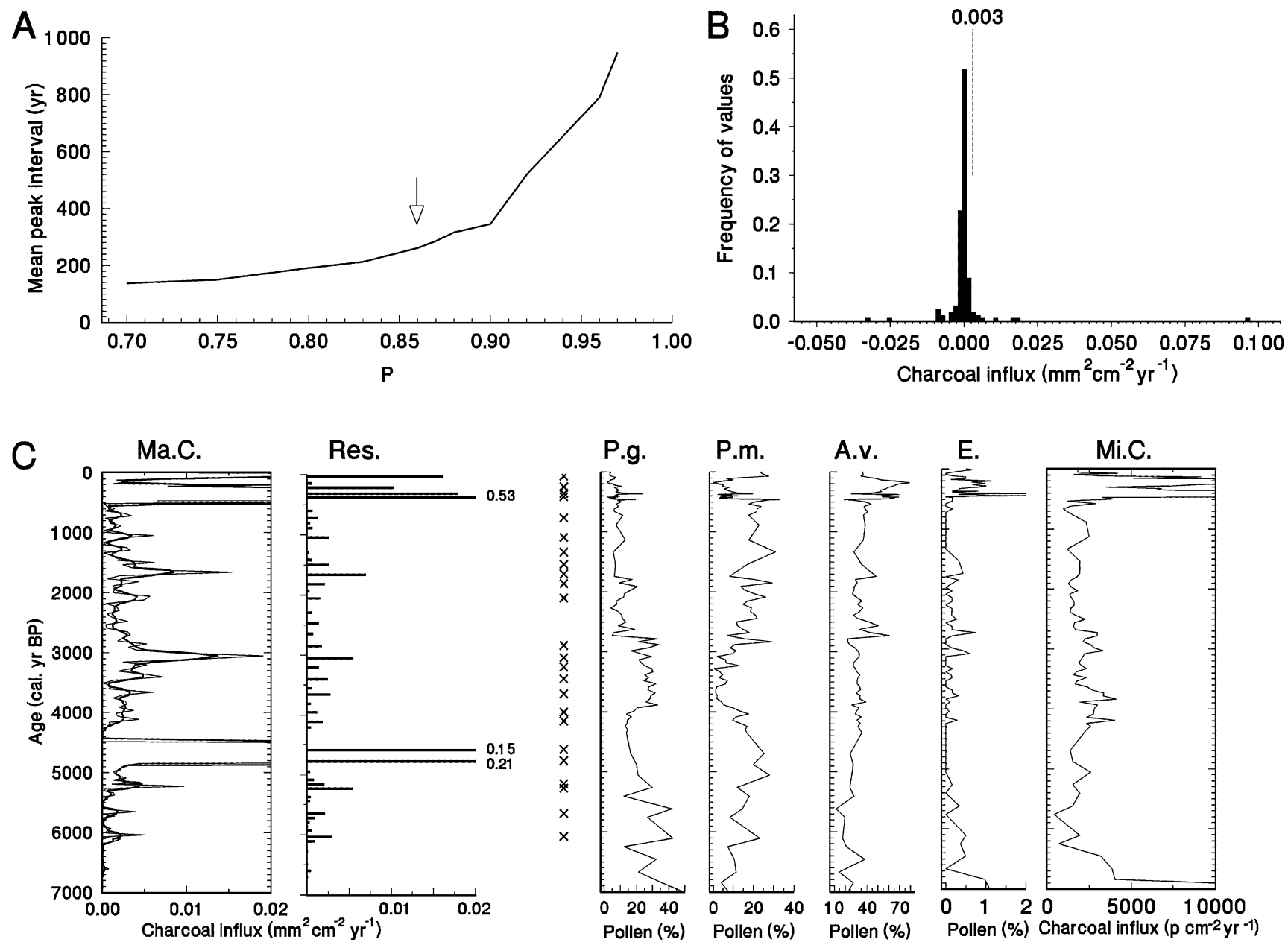

Fig. 7 Summary charcoal influx and pollen percentage diagram. A Sensitivity analysis of macroscopic charcoal results for Grizzly Lake. The arrow indicates the point $(0.86)$ where $\mathrm{P}$ is less sensitive to mean fire return interval (MFI) (Lynch et al. 2002). Fires were estimated to be $14 \%$ of the residual distribution using a $100 \mathrm{yr}$ bandwidth smoother, with charcoal peaks $>0.003 \mathrm{~mm}^{2} \mathrm{~cm}^{-2} \mathrm{yr}^{-1}$. B Distribution of residuals, $x$-axis was truncated at -0.05 and $0.1 \mathrm{~mm}^{2} \mathrm{~cm}^{-2}$ $\mathrm{yr}^{-1}$. C Smoothed charcoal accumulation rates using a $100-\mathrm{yr}$ win-

dow and residual peaks. The $x$ indicate the residual peaks used for MFI estimation (charcoal peaks $>0.003 \mathrm{~mm}^{2} \mathrm{~cm}^{-2} \mathrm{yr}^{-1}$ ). Selected pollen types (percentages) and microscopic charcoal influx $(<10,000$ particles $\mathrm{cm}^{-2} \mathrm{yr}^{-1}$ or $<3.3 \mathrm{~mm}^{2} \mathrm{~cm}^{-2} \mathrm{yr}^{-1}$ ) are given for comparison with macroscopic charcoal influx. Ma.C.: macroscopic charcoal, Res.: residual peaks, P.g.: Picea glauca t., P.m.: Picea mariana t., A.v.: Alnus viridis, E.: Epilobium, Mi.C.: microscopic charcoal

Fig. 8 Correlograms showing correlation coefficients between microscopic charcoal influx and selected pollen types for the past 9000 years. Correlation coefficients outside the lines are significant at $P=0.05$
Grizzly Lake

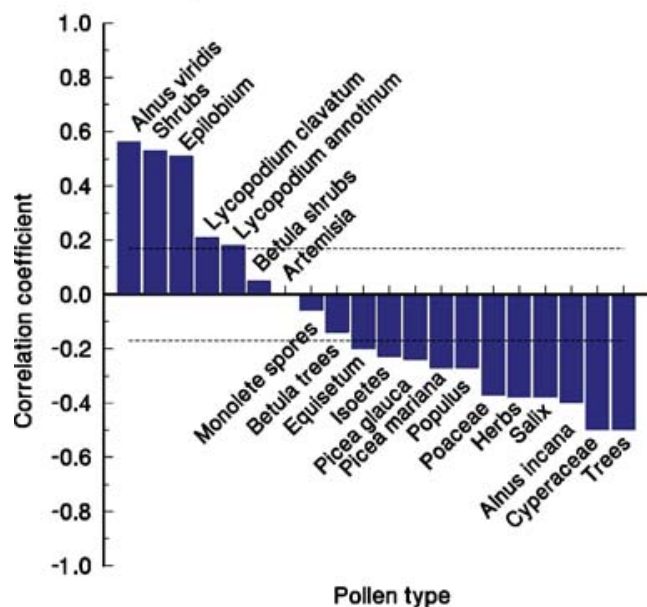

Lost Lake

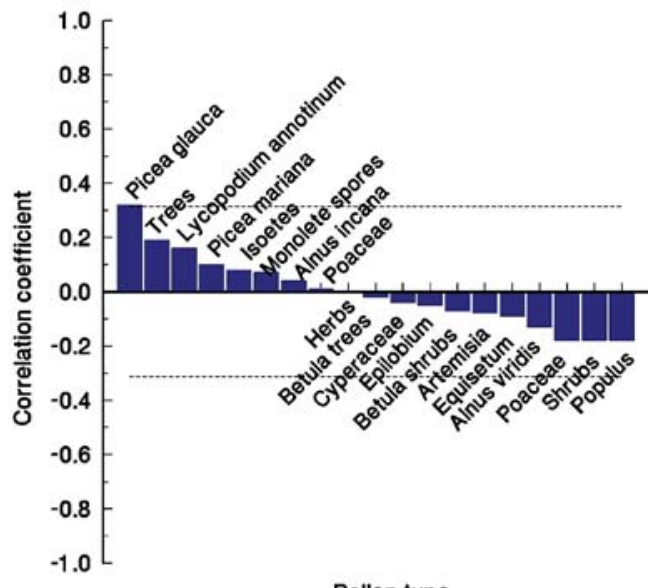

Pollen type 
Edwards 2001). However, because the chronologies of most published pollen records from Alaska are based on bulksediment radiocarbon dates, they are probably compromised by hard-water effects and/or old carbon washed in from soils of the watershed area, resulting in erroneously old age estimates. Our new record supports the speculation that at many sites across north-central Alaska, the expansion of Betula occurred later than previously estimated (Bigelow and Edwards 2001; Carlson and Finney 2004). At Windmill Lake, $120 \mathrm{~km}$ southwest of Lost Lake, Salix and Betula expansions in the lateglacial tundra occurred at ca. 14,500 and 13,500 cal B.P. respectively, which is in general agreement with the Lost Lake record (ca. 14,400 and 13,200 cal B.P.). However, only one radiocarbon date is available for the period of interest at each of these two sites.

The Salix expansion in the herb tundra at Lost Lake probably reflects climatic warming at the beginning of the Lateglacial. Around 14,500 cal. B.P. temperatures increased markedly at many areas in the northern hemisphere, by about $8-12{ }^{\circ} \mathrm{C}$ in Greenland and $4-6{ }^{\circ} \mathrm{C}$ in Europe (Björck et al. 1998; von Grafenstein et al. 1999; Lowe and Hoek 2001; Heiri and Millet 2005), leading to pronounced changes in the biosphere such as an establishment of woodland for instance in central Europe at ca. 14,500 cal B.P., the beginning of the Bølling period (Lotter 1999; Litt et al. 2001, 2003). Similarly, the replacement of herb tundra by Betula shrub tundra probably resulted from climatic warming and increased moisture at 13,500 cal B.P. (Bigelow and Edwards 2001; Hu et al. 2002). Rapid responses of Salix and Betula to climatic amelioration were possible because these shrubs probably grew in scattered localities in the herb tundra prior to 14,500 cal. B.P.

The diminished Betula shrub cover in association with the increased abundance of herbaceous taxa at 12,500-11,600 cal B.P. possibly reflects the environmental effects of the Younger Dryas, a climatic reversal characterized by cooling and/or decreased effective moisture in at least some areas of Alaska (Engstrom et al. 1990; Peteet and Mann 1994; Hu et al. 1995, 2002; Hu and Shemesh 2003). Similar patterns of vegetational change suggesting a transient opening of the Betula shrub tundra during the YD chronozone were recorded at other Alaskan sites (Hu et al. 1995, 2002; Bigelow and Edwards 2001).

Between $\sim 11,200$ and $\sim 9600$ cal B.P. Populus probably formed dense stands around Lost Lake and along rivers. Betula shrubs remained abundant, but herbaceous taxa such as Artemisia and Potentilla t. continued to decline. Popиlus stands disappeared rather abruptly at ca. $9600 \mathrm{cal}$ B.P. around Lost Lake and at ca. 9600-9400 cal B.P. around Grizzly Lake. The Populus period probably reflects the Holocene thermal maximum (HTM; Kaufman et al. 2004) and/or more alluviation (e.g. Hu et al. 1993; Bigelow and Edwards 2001) in the region, although little non-pollen evidence of the HTM exists in Alaska (Kaufman et al. 2004) and the interpretation of Populus as a temperature indicator itself is confounded by ecological processes ( $\mathrm{Hu}$ et al. 1993; Anderson and Brubaker 1994). Nonetheless, preliminary chironomid data show that summer temperatures were higher than today's during the Populus period (B. Clegg, I. Walker and F.S. Hu, pers. comm.). In addition, the onset of this period at ca. 11,200 cal B.P. corresponds to increased temperatures at 11,600-11,200 cal B.P. (Dansgaard et al. 1993; Grootes et al. 1993; Lowe and Hoek 2001) in the North Atlantic region.

In the pollen records of Lost Lake, Windmill Lake (Bigelow and Edwards 2001) and Jan Lake, $180 \mathrm{~km}$ southeast of Lost Lake (Carlson and Finney 2004), the beginning of the Populus period clearly occurred after the termination of the YD (ca. 11,600 cal B.P.). In contrast, many pollen records from Alaska with bulk sediment ${ }^{14} \mathrm{C}$ chronologies show older ages for the Populus expansion, many of which fall within the YD chronozone. Thus despite the existence of a dense network of pollen records from Alaska, well dated pollen profiles coupled with temperature-sensitive proxy data, such as chironomid assemblages, are much needed to test whether the early Post-glacial Populus communities were related to higher temperatures in Alaska.

Among the common constituents of contemporary boreal forests in Alaska are tree species of Betula, whose histories are largely unknown because previous pollen studies did not distinguish tree versus shrub Betula and because few macrofossil studies have been attempted (Hu et al. 1993). Our pollen record from Grizzly Lake suggests that Betula trees were rather common from the onset of the record at $9500 \mathrm{cal}$ в.P. Betula seeds provide independent and unambiguous evidence that Betula trees grew near this site no later than ca. 6800 cal B.P. (Fig. 6). However, it is more difficult to assess the history of tree Betula at Lost Lake, where Betula tree type pollen rarely exceeds $10 \%$. In the surface-sediment pollen assemblage of Lost Lake, Betula trees attained $10 \%$ and Betula shrubs 32\%, even though Betula trees are more common in the modern boreal vegetation around the lake (Ager 1975). A plausible explanation for the under-representation of Betula tree pollen is that $B$. neoalaskana was the only tree species in that area, whereas several Betula tree species including B. kenaica or B. kenaica hybrids (Hultén 1968) existed at Grizzly Lake as at present. As concluded by Clegg et al. (2005), among the Alaskan tree birches, Betula neoalaskana is the only species of which the pollen cannot be separated quantitatively from those of shrub birches by using the ratio of grain diameter to pore depth. Thus it is likely that the tree $B e$ tula pollen profile at Lost Lake probably does not faithfully reflect the abundance of Betula trees around this lake.

Accompanying the decline of Populus at Lost and Grizzly Lakes was the expansion of Picea glauca, which probably co-dominated the landscape with tree species of birch during the middle Holocene (Hu et al. 1993). By 9000 cal B.P., $P$. glauca had become a dominant species in the landscape at these sites (Figs. 4 and 5). Shepherdia canadensis (buffaloberry) occurred in the early Holocene spruce forests or woodlands around Grizzly Lake. As at present, S. canadensis probably occurred on nutrient-poor sandy, gravely, or rocky soils, or in recently burned areas of closed sprucehardwood forests (Viereck and Little 1994). Before 7200 cal B.P. Picea mariana occurred in small amounts at Grizzly Lake and Lost Lake. This taxon increased to reach maxi- 
mum abundance at ca. 5500 cal. B.P. at Grizzly Lake and at ca. 5000 cal. B.P. at Lost Lake. At Grizzly Lake the increase of P. mariana at $7200 \mathrm{cal}$ B.P. was accompanied by the decline of $S$. canadensis, suggesting either diminished fire activity and/or the development of organic soils around this site.

Alnus viridis expanded ca. $8500-8400 \mathrm{cal}$ B.P. in the regions of both Lost and Grizzly Lakes. As at present, this species probably formed shrub thickets along rivers, on mountain slopes, and above the treeline. The expansion of Alnus has often been interpreted as indicating elevated effective moisture, especially through increased snow, and/or climatic cooling (Anderson and Brubaker 1994; Hu et al. $1995,1998,2001)$. In most of the pollen records from central Alaska, Alnus expanded after Picea glauca (Ager 1975; Anderson et al. 1990; Hu et al. 1993; Lynch et al. 2002). Only at Windmill Lake did the Alnus and Picea glauca expansions occur approximately at the same time (Bigelow and Edwards 2001).

At Grizzly Lake, the abundance of Picea, Betula, and A. viridis fluctuated markedly after $8400 \mathrm{cal}$ в.P. (Fig. 4). For example, $P$. glauca expanded at the expense of $P$. mariana from 3900 to 2750 cal B.P. (pollen zone GY-3c). In addition, transient declines of tree Betula and P. mariana occurred at $450-150$ cal B.P. in association with the increases of $A$. viridis and Betula shrubs. Although the climatic significance of some of these pollen shifts cannot be deciphered with confidence, the vegetational changes between 450 and 150 cal B.P. correspond to the Little Ice Age. These vegetational changes probably reflect a decrease in growing season temperature (Forester et al. 1989; Hu et al. 2001). However, Alnus viridis is also a sprouter well adapted to fire disturbance (Viereck and Little 1994), and thus its increase may have resulted from increased fire activity.

Most of the vegetational fluctuations of the past 8400 years did not occur at Lost Lake, and they seemed rather unusual compared to previously published pollen diagrams, which typically did not exhibit major changes during the mid and late Holocene after the initial mass expansion of Alnus (Hu et al. 1998). Although some fluctuations in the abundance of Picea, Betula, and Alnus were observed at Windmill Lake, they were mostly represented by one sample only, so that random noise could not be excluded as a possible explanation (Bigelow and Edwards 2001). In contrast, the pollen assemblage fluctuations at Grizzly Lake are each defined by multiple samples with high pollen counts, and they probably reflect meaningful vegetational shifts, as suggested by the statistical significance of the pollen zone boundaries. We attribute these fluctuations to the greater vegetational sensitivity of the area around Grizzly Lake than at the previously studied sites because of its ecotone position. Located at $720 \mathrm{~m}$ above sea level, Grizzly Lake is near the altitudinal limits of tree Betula and Picea mariana. Thus the site is ideal for detecting the effects of climatic change on these taxa. We assume that Holocene climate cooling caused these trees to decline and that the resulting gaps were invaded by taxa more adapted to cold, such as A. viridis and shrub Betula. Indeed, such a vegetational response to climatic cooling would generate the pollen pat- terns observed during the LIA-period. In our pollen record from Grizzly Lake, marked increases of $A$. viridis and declines of trees (Picea, tree Betula) are also recorded around 2800 and $8500-8200$ cal B.P., when transient temperature declines occurred in Alaska and over the northern hemisphere (van Geel et al. 1998; Bond et al. 2001; Hu et al. 2003; Heiri et al. 2004).

For the past 7000 years the macrofossil record confirms the local presence of the most important constituents of pollen-inferred vegetation such as Picea, Betula trees, Betula shrubs, and Alnus viridis around Grizzly Lake. One distinct pattern is the increased abundance of periderms of deciduous woody taxa around 4500 cal B.P., suggesting population expansions of taxa such as Alnus viridis and shrub Betula. This vegetational change is not clearly discernable in the pollen record, although it may be related to the gradual increase in the abundance of $A$. viridis after ca. 5500-4500 cal B.P. The macrofossil record also reveals that Sphagnum bogs existed near the lake throughout the past 7000 years, as suggested by a large amount of Sphagnum leaves in the sediment. The presence of macrofossils such as Nuphar polysepalum, Potamogeton, Isoëtes muricata, and Chara suggests that these taxa were common aquatic plants in Grizzly Lake.

\section{Fire-vegetation-climate relationships}

At Lost Lake, regional fires might have been particularly important during the lateglacial tundra period, as suggested by the maximum microscopic charcoal influx values of the entire record. However, because of the chronological uncertainties that may have affected our estimates of charcoal accumulation, it is difficult to determine if fire activity indeed exceeded that of the Holocene epoch. At Sithylemenkat Lake in north-central Alaska, the highest charcoal abundance prior to the establishment of boreal forests also occurred during the Lateglacial (Earle et al. 1996), although this study applied an unusual method to quantify sediment charcoal. In addition, recent macroscopic charcoal studies in the southern Brooks Range found abundant charcoal in the lateglacial sediments, suggesting that fire frequencies during this period were probably among the highest of the Post-glacial periods (Higuera et al 2005; Hu et al. in press). Despite the fact that it is difficult to compare these studies because of their methodological differences, together they raise the possibility that in some areas in Alaska, the lateglacial tundra probably burned as frequently as the late Holocene spruce forests. This inference differs drastically from the modern fire regimes of Alaska where boreal forests generally burn much more frequently than shrub tundra. Fire was probably more important in the Lateglacial than in the modern birch shrub tundra possibly because of (1) much drier climatic conditions of the Lateglacial and (2) high availability of fine fuels in the rather dense birchtundra communities of the Lateglacial (Hu et al. in press).

During the Holocene, regional scale fire activity did not seem to have varied greatly based on the Lost Lake microscopic charcoal data, with the exception of two periods of 
markedly higher charcoal accumulation rates around 6300 and 5300 cal B.P. In the Grizzly Lake area, microscopic charcoal suggests that the Holocene fire regime was more variable. Fires were particularly important during the periods 8500 to 6800 and 450 to 150 cal B.P., as suggested by high micro-charcoal influx values. Regional fire activity was significantly higher in the Grizzly Lake region than around Lost Lake. The striking difference in microcharcoal influx between the regions possibly reflects the topographic situations of the sites, for fires are especially intensive on steep (south-facing) mountain slopes such as in the area around Grizzly Lake, whereas in flat areas fire intensity and rapidity of fire spread tend to be less pronounced.

The macro-charcoal record from Grizzly Lake offers fire history information that differs greatly from the microscopic charcoal inferences from the same site. Because macro charcoal has short dispersal ranges (Clark et al. 1996; Lynch et al. 2004a), its record indicates local fire events that may or may not be comparable with regional fire activity. In addition, we do not have macro charcoal data for the period before $6800 \mathrm{cal}$ B.P. for comparison. However, consistent with the micro charcoal results, the macro charcoal record shows peak accumulation rates with multiple fire events $450-150$ cal B.P.

The estimated MFI of $\sim 200$ years for the past 3900 years at Grizzly Lake is strikingly similar to results of local fire reconstructions at two other sites in the Copper River basin (Lynch et al. 2004a). On the basis of lithological and macrofossil data, Lynch et al. (2004a) inferred that the region became wetter during the past $\sim 4000$ years than before, and they speculated that increased lightning frequency might have increased fire frequency during the late Holocene. However, the effect of P. mariana on fire occurrence appears more equivocal at Grizzly Lake. Although the $P$. glauca dominated period before 5500 cal B.P. indeed had a lower fire frequency than during the two subsequent periods when $P$. mariana dominated the regional vegetation, $P$. mariana dominated vegetation did not burn more frequently than $P$. glauca dominated forests within the past 3900 B.P. Because of the local nature of macroscopic charcoal records (Clark et al. 1996; Lynch et al. 2004b), differences in reconstructed fire histories among these sites are not surprising, macroscopic and/or multiple macroscopic charcoal records are needed to discern patterns of vegetation-fire-climate interaction representative of each region (Hu et al. in press).

While vegetation as a control of fires has been a focus of discussion in previous fire studies in Alaska (Lynch et al. 2002, 2004a; Hu et al. in press), the effects of fire on Holocene vegetational change remain largely unknown in Alaska. We conducted correlation analyses of pollen and microscopic charcoal to assess whether fires affected vegetation at the regional scales for the past 9000 cal B.P. At Lost Lake no significant relationship exists between microscopic charcoal and pollen (Fig. 8), suggesting that fires probably did not cause major vegetational shifts (or vice versa) detectable with pollen and microscopic charcoal at these resolutions. However, at Grizzly Lake, some of the regional variations in the fire regime were accompanied by conspicuous vegetational changes. For instance, fire was important during the periods between 8500 and 6300 B.P. and between 450 to 150 cal B.P. when Epilobium (fireweed) and A. viridis increased abruptly or reached maximum abundance (Figs. 4 and 7). The significant correlation coefficients confirm that the expansions of A. viridis, Epilobium, Lycopodium clavatum, and L. annotinum, and the reduction of trees such as $P$. glauca and $P$. mariana were linked to increased fire activity (Fig. 8). This inference agrees with observed vegetational changes after stand-replacing fires in the modern boreal forests of Alaska (Viereck and Little 1994).

However, it is more difficult to explain the negative correlation between charcoal influx and several fire adapted taxa, including Salix, Alnus incana, and several herbaceous taxa such as Poaceae, Cyperaceae, and Equisetum (Fig. 8). Fire occurrence was probably not directly related to the decline of these taxa. Rather, these plants were abundant on wet soils near the lake shore, and drier climatic conditions that might have increased fire activity probably reduced the extent of their wet habitats. Similarly, the significant negative correlation between the aquatic plant Isoëtes and microscopic charcoal probably reflects the decline of Isoëtes populations because of lower lake levels under drier climatic conditions. This explanation is inconsistent with the millennial-scale fire-climate relationship characterized by an increase in fire frequency with the Holocene trend of decreasing temperature and increasing effective moisture, as documented at a number of sites in Alaska (Lynch et al. 2002, 2004a; Hu et al. in press). It is conceivable that superimposed on this millennial-scale pattern, fire occurrence at multi-decadal to multi-centennial scales increased with decreased effective moisture and the resultant increase in vegetational flammability. For example, regional fire activity increased substantially around Grizzly Lake during the Little Ice Age when the climate of south-central Alaska became drier and cooler (Forester et al. 1989). Conversely, wetter/warmer climatic conditions probably reduced biomass flammability and fire occurrence after the LIA in the Grizzly Lake area.

Similar to the Holocene millennial fire frequency pattern based on macroscopic charcoal records from Alaska, Carcaillet et al. (2001) found that fire frequency increased in eastern Canada during the late Holocene when the regional (annual) climate became wetter. The authors attributed it to greater fire season moisture deficits in dry summers under a generally wetter climatic regime of the late Holocene. In contrast, such a fire-climate relationship probably resulted from increased vegetational flammability with the development of $P$. mariana as a dominant species $(\mathrm{Hu}$ et al. 1993; Rupp et al. 2002; Lynch et al. 2002) and/or increased lightning frequency (Lynch et al. 2004a) in Alaska. Our macroscopic charcoal results from Grizzly Lake also showed increased fire frequency around 5500 cal B.P. when $P$. mariana replaced $P$. glauca as the dominant tree species. However, this relationship is ambiguous after 5500 B.P. At the centennial scales, Bergeron and Archambault (1993) reported higher fire frequency in eastern Canada during the LIA when the climate was overall drier than after the 
LIA, similar to our LIA interpretations at Grizzly Lake. These results imply that projecting the effects of future climatic changes is not straightforward for the boreal biome. This inference is broadly consistent with recent modelling studies. Simulations using general atmospheric circulation models suggest that with future climatic warming, fire frequencies will increase in some boreal regions and decrease in others in North America (Flannigan et al. 1998, 2001). Thus the relationships among fire, vegetation, and climate in the boreal forest biome are complex and dependent on time and place.

Acknowledgments We thank B. Ammann, B. Curry, J. Hollis, W. Tanner, and H.E. Wright Jr. for their great help during the coring trips. R. Shaw, S. McMillan, and F. Oberli are gratefully acknowledged for laboratory work and B. Clegg, B.Y. Lee as well as J. van Leeuwen for assistance with pollen determination. We are deeply indebted to W. Oswald, T. Brown, G. Possnert, and M. Söderman for radiocarbon dating and to the Wrangell National Park (Alaska) for permission to core in the year 2000. This study was financed by the Swiss and US National Science Foundations. We thank J. Carrión, B. Vannière, and W.O. van der Knaap for useful suggestions on the manuscript.

Dedication This study is dedicated to Brigitta Ammann. She bore this and many other projects by her steady support, encouragement, and innovative ideas. One of her most characteristic scientific attitudes is to address new questions in new landscapes with a broad set of palaeoecological tools. For instance she initiated W.T. to investigate palaeofire issues in the Alps in 1993. In 1998 she supported the idea of F.S.H. and W.T. to investigate the fire history of the Copper River Basin by offering a post-doctoral position to W.T. in Bern. Among other things this led to a Swiss NSF post-doc fellowship for W.T. to visit F.S.H. in Urbana-Champaign. This visit in 1999/2000 allowed the start of the Alaskan investigations presented in this study. During the following years Brigitta - who had joined the expedition to Alaska in 1999 - always supported our Alaskan investigations, for instance by encouraging students (R.B. and B.S.) to take over master theses on the Grizzly and Lost Lake cores or by offering laboratory assistance and financing radiocarbon dates. Thus it is difficult to express how deeply indebted we are to Brigitta for her generous, tolerant and congenial attitude during all these years!

\section{References}

Ager TA (1975) Late Quaternary environmental history of the Tanana Valley, Alaska. 54. Institute of Polar Studies, The Ohio State University, Columbus, Ohio

Anderson PM, Brubaker LB (1994) Vegetation history of northcentral Alaska: a mapped summary of late-quaternary pollen data. Quat Sci Rev 13:71-92

Anderson PM, Reanier RE, Brubaker LB (1990) A 14,000-Year Pollen Record from Sithylemenkat Lake, North-Central Alaska. Quat Res 33:400-404

Bahrenberg G, Giese E, Nipper J (1985) Statistische Methoden in der Geographie 1 - Univariate und bivariate Statistik. Teubner, Stuttgart

Bennett KD (1996) Determination of the number of zones in a biostratigraphical sequence. N Phytol 132:155-170

Bergeron Y, Archambault S (1993) Decreasing frequency of forest fires in the southern boreal zone of Québec and its relation to global warming since the end of the Little Ice Age. Holocene 3:255-259

Bigelow NH, Edwards ME (2001) A 14,000 yr paleoenvironmental record from Windmill Lake, Central Alaska: Lateglacial and Holocene vegetation in the Alaska Range. Quat Sci Rev 20:203215
Birks HJB, Gordon AD (1985) Numerical methods in Quaternary pollen analysis. Academic Press, London

Björck S, Walker MJC, Cwynar LC, Johnsen S, Knudsen KL, Lowe JJ, Wohlfarth B (1998) An event stratigraphy for the Last Termination in the north Atlantic region based on the Greenland ice-core record: a proposal by the INTIMATE group. J Quat Sci $13: 283-292$

Bond G, Kromer B, Beer J, Muscheler R, Evans MN, Showers W, Hoffmann S, Lotti-Bond R, Hajdas I, Bonani G (2001) Persistent solar influence on north Atlantic climate during The Holocene. Science 294:2130-2136

Carcaillet C, Bergeron Y, Richard PJH, Frechette B, Gauthier S, Prairie YT (2001) Change of fire frequency in the eastern Canadian boreal forests during the Holocene: does vegetation composition or climate trigger the fire regime? J Ecol 89:930 946

Carlson LJ, Finney BP (2004) A 13 000-year history of vegetation and environmental change at Jan Lake, east-central Alaska.The Holocene 14:818-827

Clark JS, Royall PD, Chumbley C (1996) The role of fire during climate change in an eastern deciduous forest at Devil's Bathtub, New York. Ecology 77:2148-2166

Clegg BF, Tinner W, Gavin DG, Hu FS (2005) Morphological differentiation of Betula (birch) pollen in northwest North America and its palaeoecological application. The Holocene 15:229-237

Dansgaard W, Johnson SJ, Clausen HB, Dahl-Jensen D, Gundestrup NS, Hammer CU, Hvidberg CS, Steffensen JP, Sveinbjörnsdottir AE, Jouzel J, Bond G (1993) Evidence for general instability of past climate from a 250-kyr ice-core record. Nature 364:218220

Earle CJ, Brubaker LB, Anderson PM (1996) Charcoal in northcentral Alaskan lake sediments: relationships to fire and lateQuaternary vegetation history. Rev Palaeobot Palynol 92:83-95

Engstrom DR, Hansen BCS, Wright HE (1990) A possible Younger Dryas record in southeastern Alaska. Science 250:1383-1385

Finsinger W, Tinner W (2005) Minimum count sums for charcoalconcentration estimates in pollen slides: accuracy and potential errors. The Holocene 15:293-297

Flannigan M, Bergeron Y, Engelmark O, Wotton M (1998) Future wildfire in the northern forests: less than global warming would suggest. J Veg Sci 9:469-476

Flannigan M, Campbell I, Wotton M, Carcaillet C, Richard P, Bergeron Y (2001) Future fire in Canada's boreal forest: paleoecology results and general circulation model - regional climate model simulations. Can J For Res - Revue Canadienne de Recherche Forestière 31:854-864

FNA (2005) http://www.fna.org/FNA/

Forester RM, Delorme LD, Ager TA (1989) A lacustrine record of late Holocene climate change from south-central Alaska. Geophys Monogr 55:33-40

Gäggeler H, von Gunten HR, Nyffeler U (1976) Determination of $210 \mathrm{~Pb}$ in lake sediments and in air samples by direct gamma-ray measurement. Earth Planet Sci Lett 33:119-121

van Geel B, van der Plicht J, Kilian MR, Klaver ER, Kouwenberg JHM, Renssen H, Reynaud-Farrera I, Waterbolk HT (1998) The sharp rise of Delta C-14 ca 800 cal B.C.: Possible causes, related climatic teleconnections and the impact on human environments. Radiocarbon 40:1163-1164

von Grafenstein U, Erlenkeuser H, Brauer A, Jouzel J, Johnsen SJ (1999) A Mid-European decadal isotope-climate record from 15,500 to 5000 years B.P. Science 284:16541557

Grootes PM, Stuiver M, White JWC, Johnsen S, Jouzel J (1993) Comparison of oxygen isotope records from the GISP2 and GRIP Greenland ice cores. Nature 366:552-554

Heiri O, Millet L (2005) Reconstruction of Late Glacial summer temperatures from chironomid assemblages in Lac Lautrey (Jura, France). J Quat Sci 20:33-44

Heiri O, Tinner W, Lotter AF (2004) Evidence for cooler European summers during periods of changing meltwater flux to the North Atlantic. Proc Natl Acad Sci USA 101:1528515288 
Higuera PE, Sprugel DG, Brubaker LB (2005) Reconstructing fire regimes with charcoal from small hollows: a calibration with tree-ring records of fire. The Holocene 15:238-251

Hu FS, Shemesh A (2003) A biogenic-silica delta O-18 record of climatic change during the last glacial-interglacial transition in southwestern Alaska. Quat Res 59:379-385

Hu FS, Brubaker LB, Anderson PM (1993) A 12000 year record of vegetation change and soil development from Wien Lake, central Alaska. Can J Bot - Revue Canadienne de Botanique 71:1133-1142

Hu FS, Brubaker LB, Anderson PM (1995) Postglacial vegetation and climate-change in the northern Bristol Bay region, southwestern Alaska. Quat Res 43:382-392

Hu FS, Brubaker LB, Gavin DG, Higuera PE, Lynch JA, Rupp TS, Tinner W (in press) How climate and vegetation influence the fire regime of the Alaskan boreal biome: The Holocene perspective. Mitigation and Adaptation Strategies for Global Change

Hu FS, Ito E, Brown TA, Curry BB, Engstrom DR (2001) Pronounced climatic variations in Alaska during the last two millennia. Proc Natl Acad Sci USA 98:10552-10556

Hu FS, Ito E, Brubaker LB, Anderson PM (1998) Ostracode geochemical record of Holocene climatic change and implications for vegetational response in the northwestern Alaska range. Quat Res 49:86-95

Hu FS, Kaufman D, Yoneji S, Nelson D, Shemesh A, Huang Y, Tian J, Bond G, Clegg B, Brown T (2003) Cyclic variation and solar forcing of Holocene climate in the Alaskan subarctic. Science 301:1890-1893

Hu FS, Lee BY, Kaufman DS, Yoneji S, Nelson DM, Henne PD (2002) Response of tundra ecosystem in southwestern Alaska to Younger-Dryas climatic oscillation. Global Change Biol 8:1156-1163

Hultén E (1968) Flora of Alaska and neighboring territories. Stanford University Press, Stanford, CA

Kaufman DS, Ager TA, Anderson NJ, Anderson PM, Andrews JT, Bartlein PJ, Brubaker LB, Coats LL, Cwynar LC, Duvall ML, Dyke AS, Edwards ME, Eisner WR, Gajewski K, Geirsdottir A, Hu FS, Jennings AE, Kaplan MR, Kerwin MN, Lozhkin AV, MacDonald GM, Miller GH, Mock CJ, Oswald WW, OttoBliesner BL, Porinchu DF, Ruhland K, Smol JP, Steig EJ, Wolfe BB (2004) Holocene thermal maximum in the western Arctic (0-180 degrees W). Quat Sci Rev 23:529-560

Lévesque PEM, Dinel H, Larouche A (1988) Guide to the identification of plant macrofossils in Canadian peatlands. Canadian Government Publishing Centre, Ottawa

Litt T, Brauer A, Goslar T, Merkt J, Balaga K, Müller H, RalskaJasiewiczowa M, Stebich M, Negendank JFW (2001) Correlation and synchronisation of Lateglacial continental sequences in northern central Europe based on annually laminated lacustrine sediments. Quat Sci Rev 20:1233-1249

Litt T, Schmincke HU, Kromer B (2003) Environmental response to climatic and volcanic events in central Europe during the Weichselian Lateglacial. Quat Sci Rev 22:7-32

Lowe JJ, Hoek WZ (2001) Inter-regional correlation of palaeoclimatic records for the Last Glacial-Interglacial Transition: a protocol for improved precision recommended by the INTIMATE project group. Quat Sci Rev 20:1175-1187

Lotter AF (1999) Late-glacial and Holocene vegetation history and dynamics as evidenced by pollen and plant macrofossil analyses in annually laminated sediments from Soppensee (central Switzerland). Veget Hist Archaeobot 8:165-184
Lynch JA, Clark JS, Bigelow NH, Edwards ME, Finney BP (2002) Geographic and temporal variations in fire history in boreal ecosystems of Alaska. J Geophys Res-Atmos 107:8152, doi:10.1029/2001JD000332

Lynch JA, Hollis JL, Hu FS (2004a) Climatic and landscape controls of the boreal forest fire regime: Holocene records from Alaska. J Ecol 92:477-489

Lynch JA, Clark JS, Stocks BJ (2004b). Charcoal production, dispersal, and deposition from the Fort Providence experimental fire: interpreting fire regimes from charcoal records in boreal forests. Can J For Res - Revue Canadienne de Recherche Forestière 34:1642-1656

Moore PD, Webb JA, Collinson ME (1991) Pollen analysis, (2nd edn). Blackwell, London

Oswald WW, Anderson PM, Brown TA, Brubaker LB, Hu FS, Lozhkin AV, Tinner W, Kaltenrieder P (2005) Effects of sample size and type on radiocarbon dating of arctic and subarctic lake sediments. The Holocene 15:758-767

Peteet DM, Mann DH (1994) Late-Glacial vegetational, tephra, and climatic history of southwestern Kodiak Island, Alaska. Ecoscience 1:255-267

Punt W, Blackmore S, Hoen PP, Stafford PJ (2005) The northwest European pollen flora - Volume VIII. In: Hoen P (ed) Webedition, http://www.bio.uu.nl/ palaeo//Research2/NEPF/volume8.htm

Ramsey CB (2001) Development of the radiocarbon calibration program. Radiocarbon 43:355-363

Reimer PJ, Baillie MGL, Bard E, Bayliss A, Beck JW, Bertrand CJH, Blackwell PG, Buck CE, Burr GS, Cutler KB, Damon PE, Edwards RL, Fairbanks RG, Friedrich M, Guilderson TP, Hogg AG, Hughen KA, Kromer B, McCormac FG, Manning SW, Ramsey CB, Reimer RW, Remmele S, Southon JR, Stuiver M, Talamo S, Taylor FW, van der Plicht J, Weyhenmeyer CE (2004) IntCal04 Terrestrial radiocarbon age calibration, 26-0 ka BP. Radiocarbon 46:1029-1058

Rupp TS, Starfield AM, Chapin FS, Duffy P (2002) Modeling the impact of black spruce on the fire regime of Alaskan boreal forest. Clim Change 55:213-233

Stockmarr J (1971) Tablets with spores used in absolute pollen analysis. Pollen et Spores 13:615-621

Stuiver M, Reimer PJ (1993) Extended ${ }^{14} \mathrm{C}$ data base and revised CALIB $3.0^{14} \mathrm{C}$ age calibration program. Radiocarbon 35:215230

Tinner W, Conedera M, Ammann B, Gäggeler HW, Gedye S, Jones R, Sägesser B (1998) Pollen and charcoal in lake sediments compared with historically documented forest fires in southern Switzerland since AD 1920. The Holocene 8:31-42

Tinner W, Hu FS (2003) Size parameters, size-class distribution and area-number relationship of microscopic charcoal: relevance for fire reconstruction. The Holocene 13:499-505

Viereck LA, Little EL (1994) Alaska trees and shrubs. University of Alaska, Fairbanks

Whitlock C, Larsen C (2001) Charcoal as a fire proxy. In: Smol JP, Birks HJB, Last WM (eds) Tracking environmental change using lake sediments. Terrestrial, algal, and siliceous indicators. Kluwer, Dordrecht, pp. 75-97

Wright HE, Mann DH, Glaser PH (1984) Piston corers for peat and lake sediments. Ecology 65:657-659

WorldClimate (2005) http://www.worldclimate.com/ 